\title{
The High Return to Private Schooling in a Low-Income Country
}

\section{Tessa Bold, Mwangi Kimenyi, Germano Mwabu, and Justin Sandefur}

\begin{abstract}
Existing studies from the United States, Latin America, and Asia provide scant evidence that private schools dramatically improve academic performance relative to public schools. Using data from Kenya - a poor country with weak public institutions - we find a large effect of private schooling on test scores, equivalent to one full standard deviation. This finding is robust to endogenous sorting of more able pupils into private schools. The magnitude of the effect dwarfs the impact of any rigorously tested intervention to raise performance within public schools. Furthermore, nearly twothirds of private schools operate at lower cost than the median government school.
\end{abstract}




\title{
The High Return to Private Schooling in a Low-Income Country
}

\author{
Tessa Bold \\ Mwangi Kimenyi \\ Germano Mwabu \\ Justin Sandefur
}

The authors acknowledge the financial support of the International Growth Centre and the UK Department for International Development (DFID) as part of the iiG, a research program to study how to improve institutions for pro-poor growth in Africa and South-Asia. The views expressed here are not necessarily those of DFID. We have benefitted from comments from Gabriel Demombynes, Charles Kenny, Karega Mutahi, Lant Pritchett, Jakob Svensson, and participants at iiG events in Nairobi (Institute for Economic Affairs), Kampala (Economic and Policy Research Council), and Oxford (Centre for the Study of African Economies).

CGD is grateful for contributions from the William and Flora Hewlett Foundation in support of this work.

Tessa Bold et al. "The High Return to Private Schooling in a Low-Income Country." CGD Working Paper 279. Washington, D.C.: Center for Global Development. http://www.cgdev.org/content/publications/detail/1425807

Center for Global Development 1800 Massachusetts Ave., NW Washington, DC 20036

202.416 .4000

(f) 202.416 .4050

www.cgdev.org
The Center for Global Development is an independent, nonprofit policy research organization dedicated to reducing global poverty and inequality and to making globalization work for the poor. Use and dissemination of this Working Paper is encouraged; however, reproduced copies may not be used for commercial purposes. Further usage is permitted under the terms of the Creative Commons License.

The views expressed in CGD Working Papers are those of the authors and should not be attributed to the board of directors or funders of the Center for Global Development. 


\section{Introduction}

Despite widespread policy interest in market solutions to public service delivery, a large literature on the effect of private schooling on academic achievement shows little or no causal benefit. In a much-cited paper, Hsieh and Urquiola (2006) find that a voucher program that dramatically expanded private schooling in Chile led to no discernible increase in test scores over time. For the U.S., Altonji, Elder, and Taber (2005) find little or no impact of Catholic schooling on test scores after controlling for selection effects. Similarly for Indonesia, Newhouse and Beegle (2011) find that private schooling has a significant, negative effect on test scores. Angrist, Bettinger, Bloom, King, and Kremer (2002) find significantly positive, but modest effects from a policy experiment in Colombia, with recipients of randomly-allocated vouchers scoring roughly 0.2 standard deviations higher than non-recipients.

In this paper we demonstrate that in a low-income African country with weak public-sector institutions, i.e. Kenya, the effect on test scores of moving to private schooling may be dramatically higher than found in previous work in the U.S., Latin America or Asia 11

Over the past decade, private school enrollment has grown rapidly in Kenya. In a companion paper, we argue that this secular trend was driven, somewhat paradoxically, by the abolition of fees in public primary schools in 2003, and the concomitant decline in the perceived quality of public schools (Bold, Kimenyi, Mwabu, and Sandefur 2011).

The main contribution of the paper lies in estimating the causal effect of private schooling on test performance for Kenyan primary school students using nationwide standardized test scores. An obvious obstacle here is the endogenous sorting of pupils. The key to our identification strategy is aggregation in the spirit of Hsieh and Urquiola (2006). The growth of private enrollment will only affect average scores in a district - aggregating over both public and private schools - inasmuch as there is a genuine causal force at work. Controlling for time-invariant district characteristics, we document a large performance advantage of Kenyan private schools, equivalent to a full standard deviation of pupil-level test scores.

Furthermore, we use survey data on households' education expenditure to show

\footnotetext{
${ }^{1}$ Notably, Cox and Jimenez (1991) show that private secondary schools perform poorly relative to government schools in Tanzania. This highlights a common feature of both the Kenyan and Tanzanian school system: while government primary schools lag behind private schools in test performance, selective government secondary schools remain competitive.
} 
Table 1: Achievement: Summary Statistics for KCPE Exams Average Score Pupils Sitting Exam

\begin{tabular}{|c|c|c|c|c|c|c|c|c|}
\hline & All & Gov't & Priv & $\begin{array}{c}\text { Priv } \\
\text { Premium }\end{array}$ & All & Gov't & Priv & $\begin{array}{l}\text { Priv } \\
\text { Share }\end{array}$ \\
\hline 1998 & 247 & 245 & 281 & $14.7 \%$ & 441,742 & 420,406 & 21,336 & $4.8 \%$ \\
\hline 1999 & 247 & 245 & 286 & $16.7 \%$ & 450,030 & 426,486 & 23,544 & $5.2 \%$ \\
\hline 000 & 247 & 245 & 288 & $17.6 \%$ & 475,9 & 449,2 & 26,696 & $5.6 \%$ \\
\hline 2001 & 247 & 244 & 291 & $19.3 \%$ & 509,325 & 476,988 & 32,337 & $6.3 \%$ \\
\hline 2002 & 247 & 244 & 291 & $19.3 \%$ & 534,865 & 495,757 & 39,108 & $7.3 \%$ \\
\hline 2003 & 247 & 243 & 297 & $22.2 \%$ & 583,439 & 539,175 & 44,264 & $7.6 \%$ \\
\hline 2004 & 247 & 243 & 297 & $22.2 \%$ & 652,224 & 598,649 & 53,575 & $8.2 \%$ \\
\hline 2005 & 247 & 243 & 290 & $19.3 \%$ & 665,644 & 600,767 & 64,877 & $9.7 \%$ \\
\hline
\end{tabular}

$\overline{\bar{A} \text { verages scores are based on school-level data, weighted by the number of pupils sitting the }}$ exam in each school. Scores are re-based each year so that the national average is constant. This re-basing preserves changes in relative performance between sub-groups of test takers.

that Kenyan private schools operate at low cost relative to public schools: nearly two-thirds of pupils in the private system pay fees less than the median per-pupil funding level in government schools.

\section{The raw achievement gap}

Our performance measure is provided by scores on the Kenya Certificate of Primary Education (KCPE) examination, administered to all pupils completing primary school nationwide, in public and private schools.

Table (1) shows the trajectory of KCPE scores over time for public and private schools separately. The raw achievement gap between these sectors is both large - ranging from $14.7 \%$ to $22.2 \%$ - and increasing over most of the period. The upward trend in private school enrollment is also visible in the share of test-takers from private schools, increasing from $4.8 \%$ in 1998 to $9.7 \%$ in 2005.

\section{Identification strategy}

We use the KCPE exam data to estimate the effect of private schooling on achievement, and further, to test whether this causal performance gap changed over time. 
The key to our identification strategy is aggregation. Clearly, private schools may outperform public schools either because of the causal influence of private schooling on scores, or the selection of more able students into private schooling, or some combination of both. However, the transfer of pupils from public to private schools will only affect average scores - aggregating over both public and private schools - inasmuch as there is a genuine causal force at work.

Following on this logic, we take as our dependent variable the average score across both public and private schools for all students of a given gender, in a given district, and a given year. These cells are chosen to be as small as possible to allow sufficient degrees of freedom for estimation, but large enough so that students cannot endogenously select out of their cell. We regress these average scores on the proportion of pupils in private schools within the gender-districtyear cell, controlling for cell-specific fixed effects. Furthermore, we control for common time trends using year dummies.

The consistency of our fixed-effects estimates hinges on the strict exogeneity of private enrolment shares conditional on an unobserved district-gender-cell effect. Translating this strict exogeneity assumption to our application, we require that (i) students choose between government and private schools within their own district, and ( $i i)$ year-to-year changes in the proportion of pupils in private schools within a given district are driven primarily by supply-side factors. The second assumption is justified in the Kenyan context given the large supply-side shock of the FPE reform. Additionally, the exogenous flow of new graduates from teacher-training colleges (combined with a hiring freeze in government schools since 2001) is a key factor behind the growth of the private system.

To be explicit about the limitations of our approach, note that the results would be compromised by district-level, idiosyncratic shocks to the demand for private schooling that also directly influence exam performance. An example of such a shock would be a district-specific (positive) income shock that increases households' ability to pay for private schooling, and also increases human capital accumulation through, say, improved nutrition.

To see more clearly how data aggregation overcomes selection bias, we write exam performance, $Y$, of individual $i$ in school-sector $j$ of district-gender cell $d$ at time $t$ as a function of district and time effects, the impact of private education, and an idiosyncratic error term.

$$
Y_{i j d t}=\rho_{0}+\rho_{d}+\rho_{t}+\left(\rho_{p 0}+\rho_{p, i j d t}\right) \text { Private }_{i j d t}+v_{i j d t}
$$

The $\rho_{p, i j d t}$ reflects the possibility of idiosyncratic returns to private schooling. Naively estimating Equation (1) by OLS using pupil- or school-level data will 
produce the following coefficient on the private school dummy:

$$
\tilde{\rho}_{p}=\rho_{p 0}+\lambda_{\rho}+\lambda_{v}
$$

where

$$
\begin{aligned}
\lambda_{v} & \equiv E\left[v_{i j d t} \mid j=p\right]-E\left[v_{i j d t} \mid j=g\right] \neq 0 \text { and } \\
\lambda_{\rho} & \equiv E\left[\rho_{p, i j d t} \mid j=p\right] \neq 0
\end{aligned}
$$

Equation (2) highlights two sources of selection bias: selection of more (or less) able individuals into private schools, $\lambda_{v}$, and selection of individuals with a higher (or lower) idiosyncratic return to private education into private schools, $\lambda_{\rho}$.

Aggregating the data into district-gender cells can overcome the first source of bias. Estimation of Equation (1) by OLS using cell-level data yields

$$
\hat{\rho}_{p}=\rho_{p 0}+\lambda_{\rho}
$$

where the $\lambda_{v}$ term drops out due to averaging. In the terminology of the evaluation literature, $\hat{\rho}_{p}$ is a local average treatment effect, measuring the average return to private schooling for those who choose to enrol in private schools.

We are also interested in whether the private-school premium changed over time, especially in the wake of FPE. We investigate this through a simple interaction term. Thus our final estimating equation is,

$$
\bar{Y}_{d t}=\rho_{0}+\rho_{d}+\rho_{t}+\rho_{p 0} \overline{\text { Private }}_{d t}+\rho_{p 1} \overline{\text { Private }}_{d t} \times \mathrm{FPE}_{t}+\bar{v}_{d t},
$$

using a panel of average KCPE scores. Equation (4) is an aggregate achievement production function that nets out all individual level and compositional sorting effects on achievement. The coefficient on Private therefore measures under plausible identification assumptions - all value added of private schools (including spillovers in achievement from peers).

\section{Results}

Table (2) shows the results from estimating variants of Equation (4), with various combinations of district and year fixed effects.

As a benchmark, columns 1 and 2 regress school-level test scores on a privateschool dummy using disaggregated school data. The estimated 'effect' of private 


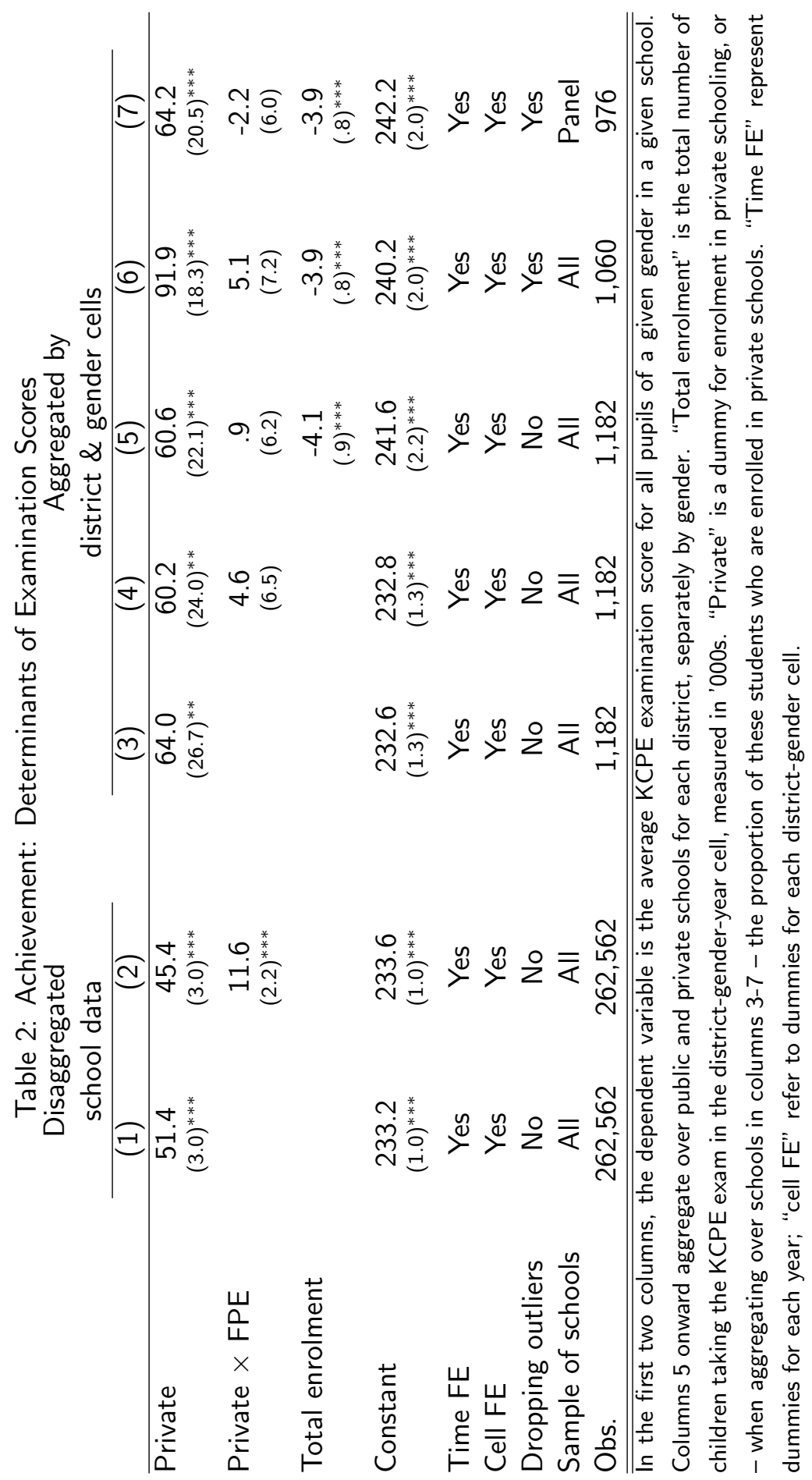


schooling is thus potentially biased by endogenous selection of more able pupils into private schools. Nevertheless, the gap between public and private schools is large (51.4 exam points) and as seen in column 2, widens significantly over time.2

Columns 3 to 7 use aggregated data from the district-gender cells, removing the effects of endogenous sorting from the estimated private-schooling coefficients. The 262,562 primary schools in the sample are collapsed into 1,182 cells, representing the 75 districts over 8 years, separated by gender. In all specifications, the private schooling effect remains large and significant. With the inclusion of both location and time effects, we find a gap between private and public schools of 64 exam points, or roughly one standard deviation of the underlying pupil-level test scores 3

Including an interaction term between the private-school and FPE dummies in columns 4-7 shows that the private-school effect did not increase under FPE. Thus the increased public-private gap in the raw data over this period shown in Table 1 is likely attributable to increased sorting of more able or better prepared pupils into private schools after FPE.

Columns 5 to 7 perform additional robustness checks. A first concern is that results may be biased by idiosyncratic increases in the overall demand for education in a district over time. To address this, we include an additional control for total enrolment spanning both public and private schools in each district cell, which acts as a time-varying proxy for the demand for education in the district. While the coefficient on this term is significant, it does not undermine the core result for private schooling. A second concern is that results may be driven by outliers. Column 6 drops districts containing the largest $1 \%$ of year-on-year changes in KCPE scores or private enrolment shares - leading to a loss of seven districts. Again, the results are qualitatively unchanged, with the private-school coefficient only increasing in magnitude. A final concern is that improvements

\footnotetext{
${ }^{2}$ Using school-level averages, the mean score in the regression sample is 247.1 , with a standard deviation of 42.5 points. However, for consistency with the literature, we report effect sizes relative to the standard deviation of the underlying pupil-level data. While we do not have access to pupil-level data for the sample used here, 2010 pupil-level data available at yelds an estimated standard deviation of 65.0 points, which we take as our denominator for effect sizes throughout the paper.

${ }^{3}$ This very large implied effect refers to a binary switch from government to private schooling, which is relevant for an individual pupil but not for a district. The national increase in the proportion of private-school test-takers from 1998 to 2005 was roughly $4.9 \%$. Thus our econometric estimates imply that this fairly dramatic expansion of private schooling led to a 5 point increase in average scores (point estimate of $64 \times 4.9 \%$ increase in private schooling), or 0.08 standard deviations of school-level average scores.
} 

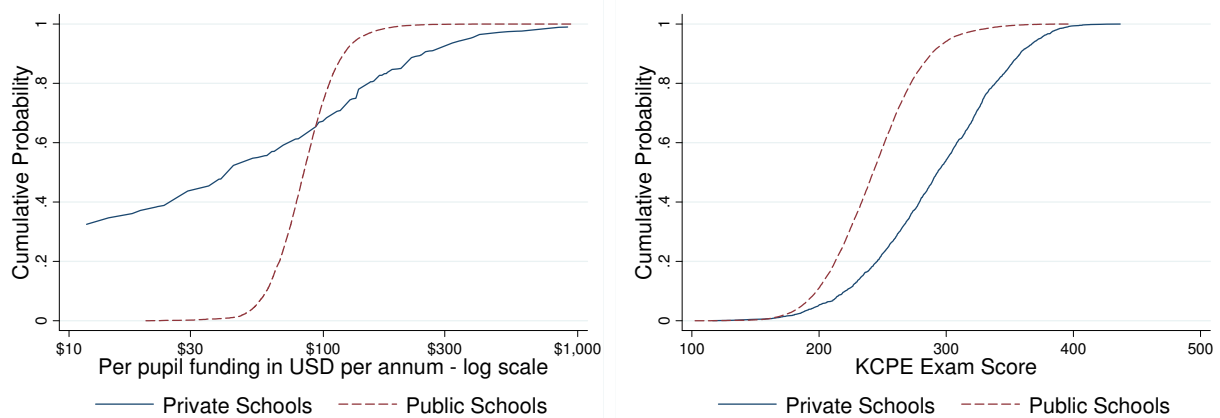

Figure 1: The distribution of funding and test scores in public and private schools

in data collection and data capture over time may have led to the inclusion of more private schools in later years, creating the illusion of private enrolment growth and performance gains. To address this concern column 7 restricts the sample to a balanced panel of schools. The estimate of the private schooling effect remains at 64.2 points.

\section{Funding}

The analysis in the previous section showed that private schooling raises test scores. It does not necessarily follow that private schooling is more efficient at delivering education, as measured by cost-benefit ratio. The superior performance of private schools may reflect an advantage in terms of financial and human resources. Direct comparison of resource levels between public and private schools is difficult because funding for each sector flows from different (and sometimes multiple) sources, requiring collation of multiple data sources.

Private schools are funded by fees. Using data from the Kenya Integrated Household Budget Survey (KIHBS), we calculate that private school fees per primary school pupil had a median of $\$ 40.87$ and a mean of $\$ 110.00$ per year in 2006.

In contrast, as of 2003 public primary schools in Kenya are forbidden from charging fees. Instead, public schools receive two resource flows from the central government. The first is a per pupil grant, equivalent to approximately $\$ 14$ per annum, transferred to a school bank account. The second resource, teaching 
staff, is provided in-kind. We place a value on teachers equivalent to their average salary divided by the pupil-teacher ratio in a given school. While salaries vary by seniority and qualification, a nationwide survey conducted by the Kenya $\mathrm{Na}$ tional Examination Council (Kenya National Examination Council 2010) found an average salary among civil service teachers of $\$ 262$ per month over twelve months in 2009 (the nearest available year), which we use as the basis for our calculations. Variation in per pupil funding in the public school system arises primarily due to differences in staffing levels, as reflected in pupil-teacher ratios. Based on administrative data from the Education Management Information System (EMIS) maintained by the Ministry of Education, in 2005 the median pupil-teacher ratio was 39.7 and the mean was 42.1 in public primary schools. Combining these figures yields a median funding level of $\$ 83.81$ and a mean of $\$ 88.42$ in public schools per pupil per annum.

Figure 1 plots the full distribution of funding and performance in public and private primary schools. In the left-hand panel, the distribution of fees paid for private schooling is juxtaposed with the distribution of per-pupil funding in government schools (combining salary, pupil-teacher ratio, and capitation grant data). Notably, these distributions cross at about the 67th percentile, or just under $\$ 100$ per year. Thus, comparing similar points in the distribution, the vast majority of private schools operate more cheaply than their public counterparts.

The right-hand panel of Figure 1 presents the distribution of KCPE scores for both public and private scores. Note that these distributions do not cross. Rather, the private school distribution is markedly and uniformly to the right of the public school score distribution.

\section{Conclusion}

We find a robust, causal exam performance premium of one standard deviation delivered by private schools. This point estimate is significantly larger than found in previous studies, and dwarfs the impact of narrower interventions within public primary schools in the micro-empirical development literature (see (Kremer 2003)). Furthermore, from a social perspective private schooling is relatively cheap: nearly two-thirds $(64 \%)$ of children in private schools pay fees less than the median per-child funding levels in public schools circa 2005/6. Taken together, our results suggest that expanding access to private schools may provide a viable route to improving education quality at relatively low cost in low-income countries with weak public school systems. 


\section{References}

Altonji, J. G., T. E. Eldder, and C. R. Taber (2005): "Selection on Observed and Unobserved Variables: Assessing the Effectiveness of Catholic Schools," Journal of Political Economy, 113(1), 151-184.

Angrist, J., E. Bettinger, E. Bloom, E. King, and M. Kremer (2002): "Vouchers for Private Schooling in Colombia: Evidence from a Randomized Natural Experiment," American Economic Review, 92(5), 15351558.

Bold, T., M. Kimenyi, G. Mwabu, and J. Sandefur (2011): "Why Did Abolishing Fees Not Increase Public School Enrollment in Kenya?," Center for Global Development Working Paper Series, 271.

Cox, D., And E. Jimenez (1991): "The relative effectiveness of private and public schools: Evidence from two developing," Journal of Development Economics, 34.

Hsieh, C., And M. Urquiola (2006): "The effects of generalized school choice on achievement and stratification: Evidence from Chile's voucher program," Journal of Public Economics, 90(8-9), 1477-1503.

Kenya National Examination Council (2010): "Community Support Teacher Baseline Survey Report," Discussion paper, Nairobi.

Kremer, M. (2003): "Randomized evaluations of education programs in developing countries: Some lessons," American Economic Review, 93, 102 106.

Newhouse, D., And K. Beegle (2011): "The Effect of School Type on Academic Achievement Evidence from Indonesia," Journal of Human Resources, 41(3), 529-557. 


\section{A Data Appendix}

\section{A.1 Test scores}

The Kenya Certificate of Primary Education (KCPE) examination constitutes the sole, nationwide, standardized test for primary students in Kenya. Our data set constitutes an unbalanced panel of all public and private primary schools in Kenya, for each year from 1998 to 2006 . It contains information on average scores achieved by girls and boys in the school, the number of test-takers of each gender, the district of the school and whether it is government or private. The test covers English, Kiswahili, math, science and history.

\section{A.2 Household survey data}

Data on fees in the private school sector is taken from the 2006 Kenya Integrated Household Budget Survey (KIHBS), a nationally-representative, household survey conducted by the Kenya National Bureau of Statistics, spanning 13,212 households.

\section{A.3 School administrative data}

For all Kenyan public schools, the Ministry of Education's Educational Monitoring Information System (EMIS) database provides information on staffing levels and enrollment. Digitized data are available for the years 2002 to 2008. 